\title{
English Teachers' Perception on English Teacher's Classroom Management at SMK Negeri 1 Pariaman
}

\author{
Irene Anes ${ }^{1 *}$ \\ ${ }^{1}$ English Department, Universitas Negeri Padang, Padang, Indonesia \\ *Corresponding author. E-mail: anesirene05@gmail.com
}

\begin{abstract}
This is a qualitative research design. The purposes of this research are to analyze of the English Teachers' Perception on English teachers' Classroom Management at SMK Negeri 1 Pariaman and to find out factors that influence the perception of English teacher's Classroom Management at SMK Negeri 1 Pariaman. Descriptive qualitative research is used by this research. The English teachers of SMK Negeri 1 Pariaman are the sample of this research. To analyze and identify of English teachers' perception on English Teacher's Classroom Management at SMK Negeri 1 Pariaman. This research used two instruments, they are video recording and field note. The techniques of collecting the data used by the researcher are interview, observation, documentation. Then the data will be analyzed by using descriptive qualitative strategy. The result showed that the teacher's language within the room used English and Indonesian. She used English for regarding $70 \%$, then she translated it into Indonesian. The students' language within the room used Indonesian for regarding $50 \%$. Students' mistakes were usually in synchronic linguistics, pronunciation, vocabulary and language use. The teacher roles within the teaching and learning method were as a planner, informer, and monitor.
\end{abstract}

Keywords: Perception, Classroom Management

\section{INTRODUCTION}

Classroom administration is an exertion of learning action by the instructor to attain the objective of learning focused on. One of an exertion of teacher classroom administration is control and overseeing the classroom discipline. Frequent instructing depends on the capacity of the instructor to oversee the classroom. Frequent occurrence of disciplinary issues within the classroom can have an impressive impact on adequacy of instructing and learning.

Managing classroom implies overseeing the complexity, at the same time contributing to the instant by moment unfurling of room life and longer story of formal instruction. There is classified classroom management components within the physical environment of the classroom such as the location, sound and consolation; the seating courses of action; the utilization of the board and the equipment required within the course[1]. Those components are related to the educator such as his or her voice and body gesture. Teachers should ace satisfactory course room administration methodologies that will offer assistance them control the lesson and make their students appreciate it instead of abhor it or consider it as an overwhelming burden.

The efficient classroom management makes successful lesson environment with a compelling learning[2]. This objective demonstrates that instructors got to have a wide develop of skills, but it does not make clear how to attain this. Classroom management as anything that the educators did to organize students, space, time and materials so that instruction in substance and learning exercises seem take place[3].This means that effective classroom administration speaks to a wide run of intuitive between instructors and students, which incorporates instructive, social, spatial and material conditions.

Classroom management very expensively as the determinate and methods essential to set up and keep up an environment in which instruction and learning can happen. More absolutely, it centers on the direction of student behavior. Classroom management alludes to the activities and methodologies instructors utilize to illuminate the issue of arrange in classroom. Hence, classroom management could be a complex work out within the handle of instruction. It requests ability, aptitudes, vitality and capacity from instructors to oversee classrooms since it directly bargains with the behaviors of learners.

As human discharge with environment is something related to sensation and perception. This investigate phenomena that give us recommendation that perception is much more required in language learning. Perception is something individual do, that something happen to us or indeed in ourselves[4]. Perception requires perceiver to get it certainly the impacts of movement on tangible incitement. 
In learning English, Senior Vocational High School is one of put for students in doing instruction learning handle. The students go to within three most noteworthy grades some time recently college. They feel inquisitive around the exercises around bolstered by all data media which are simple to get to, and completely not all data allow positive affect to them. It is the one of the teacher's obligation to put and coordinate students to the positive exercises. School and course circumstances will be more fun on the off chance that they are upheld with great classroom administration.

Literacy is anticipated in learning English in professional schools is that students can reach the level of communication and instructive since they are arranged to be able to go specifically into the world of work or proceed their instruction to college. Educator ought to have great classroom management to form their students enjoy in learning English within the classroom. With the great administration the lesson condition will more life and curiously for the students.

At that point, instructors utilize common students' situate course of action; deliberate lines. Since, the instructor needs to center on create understudy needs to how to the instructor utilize course reading to tell the fabric and do work out.

Learning dialect wiil not be maximal when it is fair centered on the content book, or content book's instruction, there are ought to be a great lesson room administration,

the instructors rarely utilize English dialect in their class. In common it can be said that students' professional school cooperation in exercises it hin the classroom is nice sufficient, within the sense that they continuously react to the assignments and informational given by the educator. Nearly all understudies carry out the exercises given with excitement. It was very obvious that they were undoubtedly understudies over normal.

These days, the instructor ought to encompasses a course room administration which make understudies dynamic, since in learning dialect, hypothesis is nothing without hone and hone needs action really. By realizing how English teachers in Vocational High School in managing their classroom, it is hoped help in giving feedback to the English teachers. This research will be conducted to identify of English Teacher's Classroom Management at SMK Negeri 1 Pariaman..

\section{LITERATURE REVIEW}

Three main theories of schoolroom management as student- directed, cooperative, and teacher directed[5].
The scholars coordinated hypothesis accepts that students have the essential obligation for dominant their behavior.

Cooperative management is predicated on the conviction that the management of scholars' behavior is that the joint obligation of students and teacher. Within educator coordinated strategy, the instructor accept essential duty of overseeing students' behavior. Students gotten to be viable choice- producers by internalizing rules and rules for behavior.

Basic purpose of classroom management aims to encourage students towards learning and to push their positive behaviors[6]. It assists content that positive classroom administration contributes to improved scholastic accomplishments of students' behavior and instructors educating. The models as 3 points on a time that move from student - directed toward teacherdirected practices[7]. The focuses could also be thought of because the convictions that instructors hold to take a particular strategy, or a mix of ways.

Online situations proceed to be a well-known choice for proficient improvement in instruction[8]. According to Internet and instructive mechanical progresses permit for a web environment that incorporates on demand conveyance of instruction, prompt get to the libraries of inquire about materials and real time interactions between teachers and students [9].

The key component of effective classroom management[10]. They are first, understanding students' individual and mental needs. At that point, making a positive classroom climate and a community of back by setting up positive teacher-student and peer connections and keeping up helpful association with students' caregivers. Third, including students in creating and committing to behavior measures that advance on task behavior and offer assistance back a calm, secure learning environment. In a few alternative purpose of the views classroom management is that the organization of a room as a learning environment: the administration of scholars discipline, organize and care; the gathering of scholars for various assignments and styles of interaction; the individualisation of scholars learning. The core part of classroom management[11].

A number of interconnection topics have developed topics have developed from the going before investigation of the nature of classrooms which reflects the involvement of teaching and learning. Classroom management is concerned with three primary strands of classroom life, space, time, cooperation and engagement.To realize this reason, this instructors may arrange normally for their lessons, plan educating and learning materials more reasonably, organize the substance, brighten classroom and set up day by day schedules. 


\section{METHOD}

This research is descriptive qualitative research. Qualitative analysis may be a sort of analysis that not embrace any shrewd or enumeration. They state that qualitative strategy may be an analysis procedure,that produces

descriptive information within the style of written or oral words from individuals and their behavior that area unit ascertained. The population of this research is the all of English Teachers of SMKN 1 Pariaman. As for the sample of this research used 2 English teachers who teach English at tenth grade. The researcher divided the population into separate groups called clusters. Then, a simple random sampling was selected from the population. To analyze and identify of English Teacher's Classroom Management at SMK Negeri 1 Pariaman. This research will use two instruments, they are video recording and field note. The techniques of collecting the data used by the researcher are interview, observation, documentation.

The data in this research analyzed by using descriptive qualitative strategy. In this research, the researcher use data analysis. It is descriptive analysis. There are three kinds activity of data analysis, they are reduction, data display, and conclusion drawing/verification.

\section{FINDING}

The result of this research showed that classroom management in learning English at SMK Negeri 1 Pariaman were well arranged. The teacher's language within the classroom used English and Indonesian.

They used English for concerning 70\%, then she translated it into Indonesian. The students' language within the classroom used Indonesian for concerning five hundredth. Learners' mistakes were usually in synchronic linguistics, pronunciation, vocabulary and language use. The teacher roles within the teaching and learning method were as a planner, informer, and monitor. The last was the academics gave feedback to the scholars throughout the lesson or within the finish of the lesson. Teacher roles within the teaching and learning method, like a controller, director, manager, helper, and resource.

\section{DISCUSSION}

The result of the study is divided the classroom management is concerned with three main strands of classroom: time and space, participation and engagement[1].

Within the category of time and space, the analyst found that the English instructors utilized great time assignment in edu cating learning prepare based on

lesson arrange of Professional tall school. It was $8 \times 45$ minutes in a week. Within the result from video recording.

The instructor connected the lesson arrange step by step but some of the time not orchestrated well. In instructing learning prepare,

the instructors overseen the classroom by taking after times from lesson arrange that they made some time recently entering the classroom. To handle the huge course, the educator for the most part utilized the routine course of action and made bunches of understudies, such as, little bunches, expansive bunches and in sets.

The instructor furthermore gave more thought to the understudies after they were doing the errands. These were nice ways that to handle the large lesson. Once the trainer was overseeing the microscopic course, the professional by and huge didn't have a lot of development. Within category of time and space, the analyst found that the English instructors utilized great time assignment in inst ructing learning prepare based

on lesson arrange of Professional tall school. It was 8 x 45 minutes in a week. Within the result from video recording. The instructor connected the lesson arrange step by step but some of the time not orchestrated well.

In instructing learning handle,

the instructors overseen the classroom by taking after times from lesson arrange that they made some time recently entering the classroom.

In engagement category, it is shown that the pattern of the students' table arrangement was the traditional arrangement [12]. during this investigate, the teacher as a rule gave input amid the lesson or among the conclusion of the lesson. During the lesson, the pedagogue checked the students' understanding of contemporary lexicon and adjusted the students' botches. The students' botches in poring over the content were in their articulation. She gave hones in articulating a couple of words. At that time she gave criticism to the scholars on an individual basis or gathering. among the conclusion of the lesson, the pedagogue summarized the

material and publicised understudies to inquire a couple of queries and challenges. In this analysis, the teacher typically gave feedback throughout the lesson or within the finish of the lesson. throughout the lesson, the teacher checked the students' understanding of latest vocabulary and corrected the students' mistakes. The students' mistakes in reading the text were typically in their pronunciation. She gave practices in saying some words. Then she gave feedback to the 
scholars on an individual basis or grouping. within the finish of the lesson, the teacher summarized the fabric and offered students to raise some queries and difficulties.

\section{CONCLUSIONS}

Based on the results of observation, regarding the management of classroom, it are often all over the management of this English classroom at SMK Negeri 1 Pariaman was varied and complicated. The results of this analysis showed that classsroom management in learning English at SMK Negeri 1 Pariaman were well organized. The teacher's language within the schoolroom used English and Indonesian. She used English for concerning $70 \%$, then she translated it into Indonesian. The students' language within the schoolroom used Indonesian for concerning 50\%.

Learners' mistakes were typically in descriptive linguistics, pronunciation, vocabulary and language use. The teacher roles within the teaching and learning method were as a planner, informer, and monitor. The last was the academics gave feedback to the scholars throughout the lesson or within the finish of the lesson.

\section{REFERENCES}

[1] Brown, H. Douglas.Teaching by Principle and Interactive Approach to language pedagogy. New York: Longman Inc.2001.
[2] Kounin, J. S .Discipline and Group Management in Classrooms. New York Holt, Rinehart and Winston. 1970.

[3] Anderson,L.H. Psychology of Classroom Learning. Classroom Management.2008

[4] De Kramer, R., O'Dwyer, L., Dash, S. \& Russell, M.The Effects of Online Teacher Professional Development on Fourth Grade .2012

[5] Levin, J., Nolan, J. F., Kerr, J. W., \& Elliot, A. E. Principles of classroom management: A professional decision-making model (1st Canadian ed.). Toronto, MacMillan.2005

[6] S. Herbert, C. Campbell, Esther Loong; Computer Science, Mathematics; Australasian Journal.2016

[7] Froyen, L. A., \& Iverson, A. M. School-wide and classroom management: The reflective educatorleader(3rd ed.). 1988

[8] Jones, V.F. \& Jones, L.S.Responsible Classroom Discipline : Creating Positive Learning Environments and Solving Problems. Boston: Allyn and Bacon.1997

[9] Wright, V.H., Sundburg, C.W., Yarbrough, S., Wilson, E., \& Stallworth, B.J. Construction of teaching metaphors through the use of technology. Electronic Journal of Integration of Technology in Education.2005

[10] Berliner, D. C. The Development of Expertise in Pedagogy. Washington, D.C. American Association of College for Teacher Education. 1988

[11] Miles, M.B, Huberman,A.M, dan Saldana,J. Qualitative Data Analysis, A. Methods Sourcebook Edition 3.2014

[12] Supriyanti, Nury.Managing the Teaching and Learning Process.Thesis 2014 